\title{
Immunology of Nonhospital and Intrahospital Infections
}

\author{
V. M. Zemskov ${ }^{a, *}$, A. M. Zemskov ${ }^{b}$, and V. A. Zemskova ${ }^{b}$ \\ ${ }^{a}$ Vishnevsky National Medical Research Center of Surgery, Ministry of Health of the Russian Federation, Moscow, Russia \\ ${ }^{b}$ Burdenko Voronezh State Medical University, Voronezh, Russia \\ *e-mail: arturrego@yandex.ru \\ Received June 14, 2020; revised June 14, 2020; accepted June 14, 2020
}

\begin{abstract}
The ecological factors of infections and their immunotropy are considered in detail, including the immunotropy of medical factors and features of community-acquired and nosocomial infectious diseases. The general patterns and mechanisms of these categories are discussed.
\end{abstract}

Keywords: infection, environmental factors, immunology of infection

DOI: $10.1134 /$ S2079086421040101

\section{INTRODUCTION}

A problematic vector in modern medicine is the accumulation of immunocompromised individuals in the population. This phenomenon is based on a number of different factors: (1) the progressive aggressiveness of the external environment, (2) a decrease in infant mortality due to a high level of resuscitationobstetric and gynecological care, which leads to the survival, accumulation, and reproduction of contingents with systemic pathology, (3) population aging, (4) the prolongation of life for patients with severe chronic pathological processes, (5) drug polypharmacy, including the widespread use of immunotropic, vaccine, serum, stimulating, suppressive, corticosteroid, analgesic, anesthetic, and other drugs, (6) the use of more than 2000 types of aggressively traumatic methods of examination and treatment of patients, (7) the negative effect per person of microflora of medicinal and other plants, soil, water, air, agricultural and domestic animals, birds, insects, and genetically engineered food products (Kalinina et al., 2008; Immunoterapiya..., 2012; Zemskov et al., 2016).

Insufficient consideration of the influence of the above factors on immune and infectious processes led to the formation of tendencies that are difficult to control. These include (1) the induction of resistance of pathognomonic microflora to antibacterial drugs, (2) weakened and perverted training of the immune system of the younger generation against the background of an increase in the number of people with deficiency, allergic, autoimmune, lymphoproliferative, and other disorders, (3) the modification of somatic, infectious, and other diseases, (4) the formation virus carriers in severe cardiovascular and other pathologies.

A decisive role in the induction, development, and outcome of infectious diseases is played by the pres- ence of an etiological infectious agent, the particular state of immunity of the microorganism, and the ecological environment.

\section{ETIOLOGICAL FACTOR OF INFECTIOUS DISEASES}

In nature, there are about 100000 species of bacteria and several hundred thousand viruses. Of these, 1000-1500 pathogens are capable of causing human diseases (Meditsinskaya mikrobiologiya..., 2004).

The sources of pathogenic bacteria, viruses, prions, protozoa, helminths, and fungi include humans (anthroponotic infections), humans and animals (anthropozoonotic), the external environment (sapronous disease of legionnaires), microflora of the soil, air, water, food products, and plants, including a number of medicinal plants, etc.

Soil microflora. The direct sanitary and bacteriological indicators of the biological load on the soil are the causative agents of intestinal infections (pathogenic enterobacteria and enteroviruses). There are four degrees of soil pollution: clean (1-10 microbial bodies per unit volume), moderately polluted (10$100)$, dangerous (100-1000), and extremely dangerous (more than 1000).

Air microflora. They include three groups of microorganisms: pyogenic forms; spore-bearing, ammonifying, and putrefactive microbes in the soil; and molds and yeasts.

Water microflora. These are the main source of infection with cholera, dysentery, typhoid fever, and other intestinal infections, as well as leptospirosis and often tularemia.

Food poisoning of microbial etiology. The following types of food poisoning are distinguished: (a) micro- 
bial, which are subdivided into toxic infections and intoxication, or toxicoses (bacterial and mycotoxicosis, mixed etiology), (b) nonmicrobial, which include poisoning by poisonous plants and the tissues of live animals (which are poisonous in nature), products of plant or animal origin (which are poisonous under certain conditions), and chemicals, (c) poisoning of unknown etiology. There are toxic infections that represent acute diseases that arise from the consumption of foods containing a large number of living cells and their toxins, which are released during the reproduction and death of microorganisms (toxicosis, intoxication). These infections are acute or chronic mycotoxicosis, i.e., diseases caused by the consumption of food containing toxins that accumulated in it as a result of the development of a specific pathogen, while viable microorganisms may be absent or found in small numbers (Mikrobiologiya dlya..., 2020).

\section{IMMUNOTROPICITY OF ENVIRONMENTAL FACTORS \\ Causes of Immunity Modification}

Complex environmental, medical, and other factors are causes of the modification of the immune system. In the case of community-acquired infections, environmental factors play a leading role, while their combination with diagnostic and therapeutic effects are the most influential in case of nosocomial infections (Khaitov et al., 2010; Allergologiya, 2014; Zemskov et al., 2017).

Environmental factors include abiotic (temperature, radiation, humidity, daylight hours, chemical composition of air, soil, water, etc.), biotic (microflora, flora and fauna), and anthropogenic (physical, chemical, medical, etc.) impacts. The action of these factors result in modification of the immunoreactivity: its increase (allergy, autoimmune diseases) or suppression (immunodeficiency, cancer), the induction of lymphoproliferative processes, etc. (Ekologicheskaya..., 1995; Federal'nye klinicheskie rekomendatsii..., 2014b).

\section{Integral Assessment of Environmental Factors}

The assessment is made up of such basic criteria as the specific state of the atmosphere, drinking water, and soil of populated areas and the food products.

Substances polluting the atmosphere. These highpriority substances include dust, sulfur dioxide, nitrogen dioxide, carbon monoxide, lead, phenol, and formaldehyde. The specific contribution of polluting emissions from vehicles is $80 \%$ of the total. Moreover, a comprehensive medical and environmental examination reveals four risk zones for the formation of immune disorders and increased infectious diseases, especially in children. These include a hazardous risk zone (large highways, sanitary protection zones of industrial enterprises and adjacent residential areas), a high risk zone (local public and business centers and industrial and transport structures), a satisfactory risk zone (marginal areas, nonindustrial zones) and, lastly, a zone of low permissible risk (absence of enterprises, highways).

Drinking water quality. The quality depends on the content of iron, manganese, nitrates, nitrites, sulfates, and chlorides, the total hardness, etc.

Contamination of the soil cover. The risk factors are heavy metals (copper, zinc, lead), the sources of which are industry, transport, etc.

Lack of nutrition. Moderate manifestations of this condition do not cause profound damage to immunoreactivity. However, with chronic protein-caloric inadequacies, there is a decrease in the activity of phagocytosis, the properdino-complementary system, and the formation of interferon, lysozyme, and Igglobulins of various classes, as well as a decrease in the content of the main populations and subpopulations of lymphocytes. A vitamin deficiency develops for retinol, riboflavin, folic acid, pyridoxine, ascorbic acid, and iron. The resistance of tissue barriers decreases, and, in combination with a lack of protein, the immunoactivity is inhibited. In persons with hypovitaminosis, infectious diseases occur more often, are more severe, and are prone to chronicity and complications. The exclusion of animal proteins from the diet causes inhibition of the humoral defense mechanisms. It is essential that the lack of nucleic acids in food, even with a sufficient caloric intake, suppresses cellular immunity. It should be emphasized that fasting, including medical fasting, to a certain extent reproduces the above effects (Zemskov et al., 2017; Osnovy mikrobiologii..., 2019).

A new direction in the monitoring of the quality and safety of food involves the control of biologically active additives (BAAs) obtained from genetically modified organisms (GMOs). A particularly significant amount of GMOs is found in poultry and poultry products. It should be recognized that the effect of GMOs on immunity and infectious pathology is little studied.

Influence of chemical environmental factors on immunoreactivity. According to the WHO, chemicals that make up the environment and production in 2004 caused 4.9 million deaths and reduced the life expectancy of the population by a total of 86 million years. In general, chemicals, the amount of which reaches 4 billion ( 63000 are used in everyday life), can enter the body and cause various disorders, e.g., general toxic and local irritant effects, desquamation of the epithelium, bronchospasm, and increased microorganism penetration through mechanical barriers. With chronic exposure, CD8-lymphocytes activation is observed, which is accompanied by the development of immune tolerance and suppression of antibody production and factors of nonspecific anti-infectious resistance. The formation of conjugated antigens and 
the induction of reactions that deplete the immune system are possible. All of these actions, in addition to the formation of immune deficiency, are also dangerous due to their mutagenic effect (Zemskov et al., 2016).

Different chemicals trigger different mechanisms of damage to the immune system. For example, chlorinated cyclic dilexins, brominated biphenyls, and methylmercury are the cause of impaired maturation of CD3 cells, atrophy of the thymus, and hypoplasia of the lymph nodes. Alkylating compounds, benzene, ozone, and heavy metals lead to immunosuppression due to DNA damage, while aromatic amines and hydrazine, respectively, result in the formation of cytotoxic antibodies (ABs) and cell clones against autolymphocytes. The use of halogen aromatic compounds and ozone is accompanied by a decrease in the production of interleukins and interferons, and the use of chlorinated cyclic dilexins leads to B-cell dysfunction and $\mathrm{AB}$ formation. Heavy metals, acridine dyes, hexachlorobenzene, and aromatic amines cause complement defects with the risk of the development of systemic lupus erythematosus. Toxic radicals of nitrogen, sulfur oxides, sulfur dioxide, quartz, coal, and asbestos lead to a deficiency of local immunity and phagocytosis of the gastrointestinal tract, lungs, and eyes, while methylmercury suppresses the suppressor function of $T$ cells with hyperreactivity of $T$ and $B$ lymphocytes. Aromatic amines, thiol poisons, mercury, and methane change the lymphocyte genotype and solubilize membrane human leukocyte antigens (HLAs), epitopes, CD molecules, and other receptors.

In the overwhelming majority of cases, chemicals affect the human body in places in which the pollution is $17 \%$ nitrogen dioxide, $14 \%$ formaldehyde, $16 \%$ nitrogen dioxide + formaldehyde, and $6 \%$ phenol$53 \%$ in total.

Influence of physical factors of the external environment on immunoreactivity. Chronic exposure to electromagnetic waves and microwave fields can cause phase fluctuations in the phagocytic activity of neutrophils and disrupt $\mathrm{AB}$ synthesis, which contributes to the development of immunopathological and immunosuppressive states. Noise at an intensity of 60-90 dB for 2 months or more contributes to inhibition of the bactericidal and complementary activity of blood serum and a decrease in the titers of normal and specific antibodies (Zemskov et al., 2008).

Radiation exposure of the body causes an increase in the permeability of the skin, subcutaneous fat, and pulmonary, blood-brain and blood-ophthalmic barriers by various microorganisms and toxins, which contributes to the development of bacterial complications. At the same time, a partial suppression of $A B$ formation is recorded up to 7-11-18 days. As a result, the maximum $A B$ production is recorded $40-50$ days after irradiation. Passive immunity is more resistant to radi- ation and is accompanied by a decrease in the therapeutic activity of immunoglobulins. Most lymphocytes are highly sensitive to radiation, especially cortical thymocytes, splenic $\mathrm{T}$ cells, and B lymphocytes. T helpers and T killers are more resistant. Small doses of radiation, as a rule, do not cause gross morphological changes in the immune system. Their effect is realized mainly at the level of functional disorders, the recovery of which is very slow and is of a cyclical nature.

Influence of regional environmental factors on immunoreactivity. Assessment of the immune status of the population (collective immunity) at the regional level must take into account that both patients and healthy people are subject to variations in immunological reactivity, depending on the climatic and geographical conditions, the national and ethnic composition, the level of industrial and anthropogenic pollution, the ecological situation, extreme conditions of life activity, and other characteristics. The highest degree of suppression of the immune status as compared to normalized values was registered in residents of the northern Caucasus, eastern Kazakhstan, and Transcaucasian regions. The highest activation of the immune status for all studied parameters was observed in the eastern Kazakhstan and central Asian regions and Kazakhstan. Analysis of the immune status of individual cities of the country found that significant immunoreactivity suppression was registered in Serzhal, Moscow, and St. Petersburg. The most successful in this regard were Kirishi, Odessa, and Rostovon-Don. Activation of immunoreactivity was noted in Karakalpakstan, Nizhny Novgorod, and Rostov-onDon. A significant total dynamics of the values of immune indicators was observed in Karakalpakstan, Armavir, and Semipalatinsk (Ekologicheskaya..., 1995).

\section{FEATURES OF NONHOSPITAL INFECTIOUS DISEASES \\ Intracellular Parasites}

The most prevalent, at present, are viruses, chlamydiae, and other pathogens that cause, among other things, slow infections (AIDS, AIDS-associated diseases). They are especially dangerous for certain risk groups: children, old people, pregnant women, postpartum women, and chronic patients. Parenteral hepatitis and urogenital chlamydia have become epidemic. The frequency of infection of the female genital organs with mycoplasmas, gardnerella, chlamydia, and other intracellular parasites has increased (Meditsinskaya mikrobiologiya..., 2007).

Influenza virus. Evidence of the variability of infections today is the variability of influenza and coronavirus pathogens, which has led to three pandemics and five epidemics over the past 100 years. In one pandemic, the 1918-1919 Spanish flu killed 50-100 million people. In the $1950 \mathrm{~s}$, the Asian flu caused two 
pandemics and was stopped in 1958. The Hong Kong flu in 1968-1969 killed 1 million people. The bird flu (AH5N1) occurred in 1997, 2003, and 2013, the swine flu (AN1N1) occurred in 1976, 1988, 2007.

Coronavirus. In 2002, there was an epidemic of severe acute respiratory syndrome (SARS) caused by the SARS-CoV coronavirus, during which 774 people died. In 2012, the Middle East respiratory syndrome caused by MERS-CoV coronavirus killed 856 people. COVID-19, a disease caused by the SARS-CoV-2 virus starting in 2019, has acquired the characteristics of a pandemic with an incidence of more than 4 million people and is currently ongoing.

Viral syndrome. The clinical signs of a viral syndrome are (1) a persistent recurrence or frequent relapses of any viral infections, (2) including episodes of acute, respiratory viral infections of various etiology in frequently and long-term ill persons, (3) "refractoriness," or the resistance of viral diseases to the methods of traditional therapy, (4) infection with herpesvirus infections with frequent relapses (HSV-1, HSV-2, Epstein-Barr virus, cytomegalovirus, etc.), (5) chronic viral hepatitis (HBV and C), (6) the persistence of viral infection (HCV), (7), an unmotivated, severe, asthenic syndrome of the chronic-fatigue syndrome type or chronic-fatigue syndrome itself, (8) persistently recurrent clinical manifestations of papillomatosis and candidiasis against the background of ongoing standard therapy. It is essential that the viral syndrome contributes to (a) the secondary development of bacterial infections, (b) a decrease in the function of the T-link of immunity in patients, (c) the formation of disorders of the interferon immunity link due to the formation of $\alpha, \beta$, and $\gamma$ interferons, (d) the induction of defects in the function of granulocytes and monocytes/macrophages. This ultimately leads to the development of nosocomial and ubiquitous infections with a high risk of death or disability (Pokrovsky et al., 2013).

To this should be added the provocation of noninfectious and other infectious diseases by the viral syndrome. Thus, the transfer of acute, respiratory viral infection (ARVI) in relatively young contingents after 6-9 months is accompanied by the development of obstructive pulmonary diseases $(57.9 \%)$, kidney diseases $(42.7 \%)$, rheumatoid lesions $(38.2 \%)$, bronchial asthma (30.5\%), and liver and biliary tract diseases (28.0\%).

Chronic fatigue syndrome. Chronic fatigue syndrome most often occurs in women aged 20-50 years. The clinical picture is characterized by easy fatigue that does not go away after rest. Daily activity is reduced by $50 \%$ for up to 6 months or more. The syndrome is accompanied by a low-grade fever, sore throat, soreness of the cervical and axillary lymph nodes (at least $2 \mathrm{~cm}$ in diameter), and headaches. There are also migratory joint pains without local manifestations, neuropsychiatric disorders (depression, disorientation, memory loss, etc.), and sleep dis- turbances. The development of a complete clinical picture occurs within 6 months, which is combined with disturbances in the ratio of regulatory subpopulations of lymphocytes due to a decrease in T-cytotoxic/suppressor CD8 lymphocytes; the accumulation of cytotoxic and effector cells; a decrease in the function of T-lymphocytes and the number of natural killers; a decrease in the levels of interleukin 2 and $\alpha$-interferon in the blood serum; and an increase in antibody titers to the Epstein-Barr virus, cytomegalovirus, herpes simplex virus, Coxsackie, measles, etc., against a background of a general deficiency of IgG (IgG1 and IgG2). In addition, autoantibodies to smooth muscles and tissues of the stomach and circulating immune complexes are detected.

\section{Modification of Bacterial Infections}

The following are currently observed: (a) increased induction of adaptive (ecological) variability of microorganisms and the transformation of zooanthroponoses (plague, yellow fever, salmonellosis) into anthroponous human diseases; (b) a change in the typical location of pathogens, e.g., Pseudomonas aeruginosa, from the intestine to other organs with the development of pleural empyema, arthritis, enterocolitis, and sepsis; (c) the formation of a positive clinical pathomorphosis, i.e., mitigation of the nature of the disease course in the form of inapparent clinical forms in combination with the frequent early or late recurrence of pathological processes (typhoid fever, salmonellosis, brucellosis, tularemia, tuberculosis, malaria, herpes, Q fever, etc.); (d) the variability of causative microorganisms with modification of the enzymatic spectrum, the emergence of new invasive factors, and changes in saccharolytic and other properties, which complicates the diagnosis of infections; (e) the formation of shig-like exotoxins (which induce diarrhea), the presence of $\mathrm{L}$ forms of bacteria and the predominance of microflora with conditional and low pathogenesis, and mixed infection, which ultimately modifies the clinical picture of diseases and complicates treatment and prevention. There is also a change in etiological factors; acutely infectious diseases in the past (smallpox, plague, classical cholera) gave way to less aggressive pathological processes, e.g., Eltor cholera, and a predominance of the ornithogenic pathway of pathogen circulation is noted (Zemskov et al., 2017).

\section{IMMUNOTROPICITY OF MEDICAL FACTORS}

\section{Traumatic Diagnostic and Therapeutic Procedures}

There are more than 2000 types of aggressive diagnostic and therapeutic interventions (catheterization, bronchoscopy, gastroscopy, heart-lung machine, anesthesia machines, etc.), that disrupt mechanical barriers, change the biocenosis of the skin and mucous membranes, and contribute to contamination with 
antibiotic-resistant strains. For example, it is known that the internal area of anesthesia devices is practically not disinfected (Belozerov et al., 2011).

\section{Pharmacological Medicinal Preparations}

All pharmacological agents are immunotropic. Broad spectrum antibiotics, corticosteroids, cytostatics, antihistamines, pain relievers, anesthetics, and other drugs have an immunosuppressive effect. Metabolics, antioxidants, vitamins, medical enzymes, plasma-substituting solutions, and hepatoprotectors activate immune reactivity. At the same time, polypharmacy is dangerous; it represents the therapeutic or uncontrolled consumption of drugs without objective reasons in violation of the schedule of administration, dosages, or treatment courses and the use of incompatible combinations of drugs (Khaitov et al., 2009; Novikov, D.K. and Novikov, P.D., 2009).

\section{Vaccinations}

The use of vaccines in the prosthetics of the population's immune system makes a significant contribution to the modification of infections, since there are about 150-200 million people annually in the Russian Federation who are subjected to active and passive immunoprophylaxis and therapy (Vaktsiny $i$ vaktsinatsiya, 2014). Such an impact can be accompanied by a number of significant effects: (1) a negative vaccine phase in some individuals (suppression of anti-infectious protection for 10-14 days) and unwanted vaccine reactions and complications; (2) defective vaccine immunity (in alcoholics, immunologically compromised individuals, allergic patients, against the background of an excess of antibodies, and in those taking antihistamines and antibacterial drugs); (3) a possible change in the action of drugs against the background of vaccines, sera, immunomodulators, etc.; (4) an unreasonably high frequency of contraindications and medical reasons for vaccinations with prophylactic drugs that have a reduced amount of antigens (DTP-M, DSM), which reduces the overall effectiveness of vaccinations; (5) violation of the storage regulations or the administration of preventive and therapeutic vaccines; (6) a sharp decrease due to known reasons, e.g., vaccinations against smallpox, which weakens the implementation of the nonspecific effect of vaccinations and leads to an imbalance in the stimulation of natural anti-infectious resistance; (5) antigenic overload and the unjustified administration of immune drugs to children with an immature immune system, which causes not only reactogenic but also vaccination reactions, complications, diseases, immune paralysis, encephalitis, type-2 diabetes, cardiovascular and autoimmune pathology, etc. It is important to note that smallpox, prickly heat, and some other infections have completely disappeared due to global vaccination. This disrupts the balance of microorganisms that has developed over hundreds of millions of years and may have unpredictable consequences for mankind, animals, and plants. An example is the ever-increasing role in human pathology of T-cell leukemia viruses, hepatitis, oncoviruses, mad cow prions, modified influenza pathogens, etc. (Chereshnev and Shmagel, 2014).

\section{Surgical Stress}

Surgical stress is a powerful factor in the suppressive effect on the immunoreactivity of patients. It is realized in two stages. The first stage develops within a few days after the surgery and is corrected in some cases without treatment. The second stage occurs 23 weeks after surgery, and, as a rule, is not eliminated. In the long term, it causes various complications, often in the form of purulent processes. During surgical interventions, there is a decrease in the content of neutrophils, monocytes, T and B lymphocytes, activated $\mathrm{T}$ cells in the peripheral blood, the reaction of the blast-transformation of lymphocytes (RBTL) with the mitogen phytohemagglutinin (PHA), natural killer cells, delayed-type hypersensitivity (DTH), interleukin 2, and the accumulation of $\mathrm{T}$ helper 2 cells (humoral immunity) against the background decrease in T-helper 1 cells (cellular immunity), which induces the formation of infectious complications. To this should be added the distortion of the formation of the cytokines interleukins- 2 and -4 , progesterone, etc. In this case, the absorption and metabolic capacity of phagocytes is disturbed. The formation of immune disorders in surgical patients is accompanied by the induction of DTH to the antigens of the causative agents of diphtheria, tetanus, tuberculosis, Proteus vulgaris, Streptococcus, Staphylococcus, E. coli, and Candida. Blood loss helps to reduce the formation of proinflammatory interleukins-2, $-3,-6, \gamma$-interferon, and the RBTL to T and B mitogens (Osnovy mikrobiologii..., 2019).

\section{Surgical Stress}

Surgical stress affects the patient's immunoreactivity via modification of the hormone production.

ACTH (adrenocorticotropic hormone). ACTH inhibits the migration of peripheral lymphocytes, $\mathrm{T}$ and B cells, and bone-marrow stem elements. This is combined with suppression of the antibody production, the proliferative response of lymphocytes, and the formation of immunoglobulins of the main three classes.

Cortisol. Cortisol reduces the formation of proand anti-inflammatory cytokines, interferons, prostaglandins, histamines, and other biogenic amines. In addition, phagocytosis, the adhesion of monocytes and macrophages at the focus of inflammation, and factors of humoral immunity are inhibited in patients. 
Growth hormone and insulin. These and some other hormones in surgical patients promote the activation of cellular and humoral immunity, killer cells, cytokines, the ratio of the free-radical oxidation of lipids and proteins, and factors of the antioxidant system.

\section{Pregnancy and Childbirth}

Postpartum infectious and inflammatory diseases in puerperas occur in $13.3-54.3 \%$ of cases, ranking second to fourth among the causes of maternal mortality. Caesarean sections increase the risk of complications by five to ten times. Peritonitis and sepsis develop in $0.47-2 \%$ of puerperas with a mortality rate of $32.9 \%$. A transient, partial immunodeficiency forms (a decrease in the absolute number of B lymphocytes and "zero" cells (large granular lymphocytes), proliferative lymphocyte activity, IgG concentration in the blood serum) in women in labor and in parturient women. Upon the development of inflammatory complications after childbirth, lymphopenia and a significant decrease in the absolute number of $\mathrm{T}$ and B lymphocytes, an imbalance of regulatory subpopulations of lymphocytes, a deficiency in the concentrations of $\mathrm{IgG}$, IgM and $\mathrm{IgA}$, complement, an excess of circulating immune complexes, and inhibition of the phagocyte absorption capacity are noted. This is combined with the discharge of the mucous plug, which is an important element of the antibacterial barrier; it washes from the mucous surfaces of the genital tract local factors of anti-infectious resistance (secretory $\operatorname{IgA}$ ) and normal microflora (Doderlein sticks), and there is a decrease in the total bactericidal acidity of the vaginal contents. As a result, already $6 \mathrm{~h}$ after the outflow amniotic fluid, practically no antiinfectious barrier of the female reproductive tract remains, and the degree of contamination and the nature of microflora depend on the duration of the anhydrous gap (Zemskov et al., 2008).

\section{Therapeutic Medical Technologies}

Nosocomial infections are divided by technology type into (1) infections associated with devices (with artificial ventilation of the lungs, bladder catheterization, vascular catheterization, etc.); (2) infections associated with medical procedures (blood transfusion, injections, etc.); (3) surgical interventions, which are divided into superficial, deep, organs or cavities; and (4) exogenous and endogenous infections. The unconditional, exogenous infection of patients has an advantage: it excludes the endogenous mechanism associated with the activation of conditionally pathogenic flora in burn patients during surgical interventions on the intestines; ear, nose, and throat organs, and other cases.

\section{CURRENT FEATURES OF INTRAHOSPITAL INFECTIOUS INCIDENTS}

Nosocomial infections (NCIs) develop in hospital, outpatient, and other organizations carrying out medical activities, including at home. The formation of NCIs is facilitated by the features of the medical organization. In the Russian Federation, the total area of all health care facilities $\left(15-16 \mathrm{~km}^{2}\right)$ contains more than 3 million beds, where 70 million patients and medical workers are accommodated for 1.2 billion days/year. At the same time, the unified air conditioning system, sewerage system, common catering units, clearance service, etc. in large hospitals contribute to the cross-infection of patients and doctors.

In general, NCIs account for $2-30 \%$ of the total number of infectious diseases in hospitals with a mortality rate of $3.5-60 \%$; it is up to $100 \%$ in generalized forms and up to $50 \%$ for detection at autopsy. Infections are observed in any health care facility: with a frequency of 46.7 cases per 1000 in surgical clinics, $36.6 / 1000$ in therapeutic clinics, 28.1/1000 in gynecological clinics, $15.3 / 1000$ in maternity wards, and $13.9 / 1000$ in in pediatric clinics. After each week of hospitalization, the number of infected persons increases by $10 \%$. In total, nosocomial infections are divided into purulent-septic, airborne, acute, and intestinal infections and viral hepatitis (Zemskov et al., 2016).

\section{Susceptibility and Contingents of Increased Risk of Nosocomial Infections}

A feature of nosocomial infections is that they affect only certain patient contingents. The likelihood of the development an infectious disease in patients at a medical facility depends on many factors, including the properties of the pathogen ("hospital strain"), the size of the infecting dose, and the state of general and local immunity, i.e., susceptibility.

\section{Factors Affecting the Body's Susceptibility to Infections}

Factors affecting the body include (1) age (newborns, children, women in labor, postpartum women, the elderly); (2) malnutrition and alimentary dystrophy; (3) concomitant chronic somatic diseases; (4) changes in normal microflora; (5) impaired immune status (Federal'nye klinicheskie rekomendatsii..., 2014a); (6) violation of dermal integrity (extensive burns, wounds); (7) invasive diagnostic and treatment procedures; (8) an unfavorable environment (ionizing and nonionizing radiation and other abiotic factors) (Zemskov et al., 2016).

\section{Features of Nosocomial Infections}

Nosocomial infections have the following features: (1) pathogens do not have pronounced organ tropism, 
since the same species can be the cause of various diseases, organ damage; (2) there is polyetiology, in which the same nosological form of the disease can be caused by different opportunistic microorganisms; (3) the clinical picture of infections depends more on the affected organ than the pathogen type; (4) infections often proceed as a hybrid of mixed infections with open or, less often, closed processes, usually with a chronic rather than an acute course; (5) the chronic course of the infection may immediately have a slowly progressive variant, or the initial pathological acute process can turn into a protracted chronic one; (6) infections have a pronounced tendency toward generalization and complications based on a decrease in localization of the body's capabilities (defective inflammation); (7) infections are characterized by slow development and a low intensity of acquired immunity, which causes refraction to the therapy; (8) infectious agents have a wide multiresistance to antibacterial drugs, high heterogeneity and variability, and a connection with autoinfectious agents with a variety of sources of infection (Mikrobiologiya dlya..., 2020).

Lesion spectrum. The lesion spectrum in nosocomial infections is extremely wide. It covers meningitis, encephalitis, mastitis, pneumonia, septic endocarditis, lesions of the genitourinary organs, purulent infections of soft tissues, infection of the perianal zone, wounds, including postoperative wounds, burns, deep pyoderma, diarrhea, sepsis, septicopyemia, etc.

State of the immune system. One of the causes of the formation of hospital infections is damage to the skin or mucous membranes and the formation of immunodeficiency states. In such patients, an imbalance in the indices of the immunity $\mathrm{T}$ link, excessive activation of humoral defense reactions, especially the formation of "heavy" immunoglobulins of class $\mathbf{M}$, the failure of phagocytosis, which is manifested by a disproportion between the absorptive and oxygenproducing capacities of the corresponding cells, and typical changes in the cytokine status (Khaitov, 2011).

Special studies found that, when patients with nonspecific inflammatory lung diseases are admitted to the clinic within 5-7 days of hospitalization, the pathognomonic strain is replaced with a hospital one, the variation of the typical picture of immune disorders is replaced by the formation of an imbalance of cellular and humoral mechanisms, regulatory subpopulations of lymphocytes, immunoglobulins of different classes, the absorption and metabolic abilities of phagocytes, and pro- and anti-inflammatory cytokines.

Etiology of causative agents of NCIs. The circulation of several hundred types of pathogenic and opportunistic pathogens of anthroponoses, zoonoses, and sapronoses has been established in health care facilities. By the nature of infection, they are mainly mixed (a combination of bacteria with viruses, proto- zoa, and fungi). In principle, hospital infections can cause obligate, facultative, and saprophytic microorganisms in the parasitic phase of existence. In this case, pathological processes usually proceed simultaneously or sequentially, layering on top of each other. Among the causative strains are staphylo- and streptococci, Pseudomonas aeruginosa, serratia, listeria, micobacteria, fungi of the genus Aspergillus, cryptococci, candida, toxoplasma, pneumocystis, and human herpes viruses of types I, II, and IV. In principle, the development of bacterial, fungal, and viral superinfections is possible. Eosophagitis, keratitis, enteritis, encephalopathy, and encephalitis are not uncommon.

Gram-negative bacteria are represented by nonfermenting bacilli (intestinal, Pseudomonas aeruginosa, acinetobacter), Klebsiella, Proteus, Enterobacter, and Serratia and account for $49 \%$ of hospital infections with damage mainly to the urinary tract. Gram-positive pathogens are represented by staphylococci, streptococci, and enterococci and cause $45 \%$ of infections, especially in surgical, obstetric, pediatric, and oncological hospitals. In $15-72 \%$ of cases, infections are shed from medical personnel. Legionella thrive in airconditioned water and cause outbreaks of pneumonia in closed settings, and spore anaerobes cause colitis in children, especially at high doses of antibiotics. In recent years, the role of mycoses in hospital infections has increased. Moreover, the same should be said about rotavirus infections that cause severe diarrhea in children.

According to a number of authors, one of the patterns of the etiology of NCIs is the high rate of pathogen evolution, which is manifested by the following processes: (1) expansion of the species composition of nosocomial pathogens, primarily from the number of opportunistic and saprophytic bacteria and fungi; (2) an increase in number in the etiology of NCIs of enterobacteria, nonfermenting gram-negative bacteria (Pseudomonas, Acinetobacter, Alcaligenes and others), coagulase-negative staphylococci, and nonclostridial anaerobes; (3) an increase in NCI resistance to antibiotics, antiseptics, and disinfectants and, as a result, a change in the etiological role of various groups of bacteria in NCI development; 4) the development of new biotopes by NCI pathogens in the human body and the growing adaptation of bacteria to the conditions of existence in them, which lead to an increase in recurrent and chronic forms of the disease and the formation of stable bacterial and bacterial-fungal associations in various hospitals. The evolution of nosocomial pathogens also depends on the types of hospital, the nosological forms of diseases, the nature of surgical interventions, the diagnostic and treatment methods, the nature of antimicrobial measures, and the scale and types of use of antimicrobial agents, antibiotics, antiseptics, and disinfectants (Rukovodstvo..., 2005; Mikrobiologiya dlya..., 2020). 


\section{CURRENT GENERAL FEATURES OF NONHOSPITAL AND IN-HOSPITAL INFECTIONS}

The general features of the incidence are expressed by (1) the high frequency of the development of secondary complications, asymptomatic carriage, persistence, systemic and local dysbacteriosis, immune disorders (deficits, allergization, autoimmune lesions), and the formation of microflora resistance to antibacterial drugs. The microbe group ESKAPE ("run and don't look back"), which include Enterococcus faecium, Staphylococcus aureus, Klebsiella pneumoniae, Acinetobacter baumannii, Pseudomonas aeruginosa, and Enterobacter, contains species that are not sensitive to most antibiotics (Mikrobiologiya dlya..., $2020) ;(2)$ the presence of risk groups for the formation of infectious diseases, which include age (childhood, puberty, menopause, old age); (3) a decrease in the quality of life of the population (low birth rate, inferior offspring, chronic diseases, drug addiction, substance abuse, alcoholism, etc.), inadequate nutrition (genetically engineered products, decreased sanitary and hygienic standards, starving people, vitamin deficiencies) and weakness, chronic stress, double aging of the population with the need for frequent treatment and diagnosis, the development of malignant neoplasms, and age-related withering of the immune system; (4) the destruction of the ozone layer and other structures with the resulting accelerated evolution of microorganisms, plants, animals, and humans, the emergence of new epidemic clones, the induction of adaptive variability of microorganisms, and the formation of immunopathological disorders; (5) migration (refugees), crowding, urbanization of the population, aggressiveness of environmental factors, climate, tourism, sex-tourism, a decrease in the sanitary and hygienic conditions and the genetic variability of microorganisms, the rapid spread of pathogens from endemic foci, geographical stress, and negative trends in population immunity.

\section{CONCLUSIONS}

The new epidemiological conditions require (1) modification of the vaccination strategy, paying attention to the prevention of the return of "old" infections due to the refusal of mass vaccinations of children, even in the absence of morbidity; (2) the creation of vaccines against "new" pathogens "based on a global system for the early detection of unknown infectious pathogens with genetic-engineering technologies; and (3) the creation and implementation of an adequate ideology for the use of immunomodulators, immunosuppressants, immunostimulants, monoclonal antibodies, polymerase chain reaction, and nanotechnology for the early prevention and treatment of "new" infections.

\section{COMPLIANCE WITH ETHICAL STANDARDS}

Conflict of interests. The authors declare that they have no conflicts of interest.

Statement on the welfare of humans or animals. This article does not contain any studies involving animals performed by any of the authors.

\section{REFERENCES}

Allergologiya: Federal'nye klinicheskie rekomendatsii (Allergology: Federal Clinical Recommendations), Khaitov, R.M. and Il'ina, N.I., Eds., Moscow: Farmarus Print Media, 2014.

Belozerov, E.S., Mitkovskaya, O.A., and Zhdanov, K.V., Klinicheskaya immunologiya i allergologiya: Rukovodstvo (Clinical Immunology and Allergology: Manual), Elista: Dzhangar, 2011.

Chereshnev, V.A. and Shmagel', K.V., Immunologiya. Uchebnik dlya studentov vuzov (Immunology: Manual for Higher Education Students), Moscow: Tsentr Strategicheskogo Partnerstva, 2014.

Ekologicheskaya immunologiya (Ecological Immunology), Khaitov, R.M., Pinegin, B.V., and Istamov, Kh.I., Eds., Moscow: VNIRO, 1995.

Federal'nye klinicheskie rekomendatsii po diagnostike i lecheniyu bol'nykh pervichnymi immunodefitsitami s narusheniyami gumoral'nogo zvena (Federal Clinical Recommendations for Diagnostics and Treatment of Patients with Primary Immunodeficiencies and Disorders of the Humoral Systems), Moscow: Ross. Assots. Allergol. Klin. Immunol., 2014a.

Federal'nye klinicheskie rekomendatsii po diagnostike i lecheniyu lekarstvennoi allergii (Federal Clinical Recommendations for Diagnostics and Treatment of Drug Allergy), Moscow: Ross. Assots. Allergol. Klin. Immunol., 2014b.

Immunoterapiya. Rukovodstvo dlya vrachei (Immune Therapy: Manual for Physicians), Khaitov, R.M. and Ataullakhanov, R.I., Eds., Moscow: GEOTAR-Media, 2012.

Kalinina, N.M., Ketlinskii, S.A., Okovityi, S.V., and Shulenin, S.N., Zabolevaniya immunnoi sistemy. Diagnostika i farmakoterapiya (Diseases of the Immune System: Diagnostics and Pharmacotherapy), Moscow: Eksmo, 2008.

Khaitov, R.M., Immunologiya (Immunology), Moscow: GEOTAR-Media, 2011.

Khaitov, R.M., Pinegin, B.V., and Yarilin, A.A., Rukovodstvo po klinicheskoi immunologii. Diagnostika zabolevanii immunnoi sistemy (Manual on Clinical Immunology: Diagnostics of Diseases of Immune System), Moscow: GEOTAR-Media, 2009.

Khaitov, R.M., Ignat'eva, G.A., and Sidorovich, I.G., Immunologiya. Norma i patologiya (Immunology: Normal State and Pathology), Moscow: Meditsina, 2010.

Meditsinskaya mikrobiologiya, virusologiya i immunologiya: Uchebnik dlya studentov meditsinskikh vuzov (Medical Microbiology, Virology, and Immunology: Manual for Students of Medical Higher Education Institutions), Vorob'ev, A.A., Ed., Moscow: Med. Inf. Agentstvo, 2004. 
Meditsinskaya mikrobiologiya: Uchebnoe posobie dlya vuzov (Medical Microbiology: Manual for Higher Education Institutions), Pokrovskii, V.I., Ed., Moscow: GEOTAR-Media, 2007.

Mikrobiologiya dlya meditsinskikh spetsial'nostei. Uchebnik (Microbiology for Medical Professionals: Manual), Zemskov, A.M., Ed., Moscow: Knorus, 2020.

Novikov, D.K. and Novikov, P.D., Klinicheskaya immunopatologiya (Clinical Immunopathology), Moscow: Meditsinskaya Literatura, 2009.

Osnovy mikrobiologii i immunologii. Uchebnik (Fundamentals of Microbiology and Immunology: Manual), Zemskov, A.M., Ed., Moscow: KNORUS, 2019.

Pokrovskii, V.I., Pak, S.G., Briko, N.I., and Danilkin, B.K., Infektsionnye bolezni i epidemiologiya: uchebnik (Infection Diseases and Epidemiology: Manual), Moscow: GEOTAR-Media, 2013, 3rd ed. http://old.studmedlib.ru/book/ISBN9785970425787.html.

Rukovodstvo po klinicheskoi immunologii, allergologii, immunogenetike i immunofarmakologii (Manual on Clinical
Immunology, Allergology, Immunogenetics, and Immunopharmacology), Pokrovskii, V.I., Ed., in 2 vols., Moscow: Triada, 2005.

Vaktsiny $i$ vaktsinatsiya: Natsional'noe rukovodstvo (Vaccines and Vaccination: National Guide), Zverev, V.V. and Khaitov, R.M., Eds., Moscow: GEOTAR-Media, 2014.

Zemskov, A.M., Esaulenko, I.E., Chereshnev, V.A., et al., Immunologiya: uchebnik (Manual on Immunology), Moscow: GEOTAR-Media, 2016. http://www.studentlibrary.ru/ru/book/01-GEO-201601.html.

Zemskov, A.M., Esaulenko, I.E., Chereshnev, V.A., et al., Kurs lektsii po klinicheskoi immunofiziologii: Uchebnik dlya studentov meditsinskikh vuzov (Course of Lectures on Immunephysiology: Manual for Students of Medical Higher Education Institutions), Voronezh: Ritm, 2017.

Zemskov, A.M., Zemskov, V.M., and Karaulov, A.V., Klinicheskaya immunologiya: uchebnik (Clinical Immunology: Manual), Moscow: GEOTAR-Media, 2008. 